JP LPPM UNRI, ISSN: 2086-4779, e-ISSN: 2715-8209

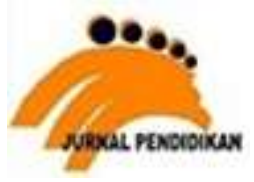

Jurnal Pendidikan

https://jp.ejournal.unri.ac.id/index.php/JP/index

\title{
NILAI - NILAI PENDIDIKAN BUDI PEKERTI MASYARAKAT JAWA DALAM TRADISI MAGUTI
}

\author{
Kodrat Eko Putro Setiawan \\ Universitas PGRI Madiun \\ kodratekoputrosetiawan08@gmail.com
}

\begin{abstract}
Maguti is a tradition that still exists in the Ngawi community, East Java. This study aims to describe the meaning of equipment symbols and the process of implementation as well as the values of character education contained in the Maguti tradition. The method used in this research is qualitative method. This research was conducted in twenty places in Ngawi Regency, namely Jagir Village, Tulakan, Bayem Taman, Bayem Sidoarjo, Jagir Krajan, Kalitengah, Tempon, Kedungjambe, Plembeku, Gedangan, Mojoagung, Miripencil, Mirirejo, Tretes, Duwet, Duwet Plasong, Duwet Dawungan, Mojorejo, Jomblang, Sampung, Karangdempel. Equipment and process in the implementation of the Maguti tradition as the main study in this study. This research was conducted in Ngawi, East Java, Indonesia. The results of the study are that there are symbols in the form of equipment and the process of implementing the tradition of Maguti. Equipment in the tradition of Maguti are bucu, jenang abang putih, jenang sepuh, banyu suci, kembang setaman, sego udhuk, sego golong, gedhang setangkep, asahan, kopat lepet. Budi Pekerti's educational values contained in the Maguti tradition are religious values, values of independence, values of caring, values of responsibility, values of mutual respect, values of honesty, and creative values.
\end{abstract}

Keywords: Maguti, Budi Pekerti's Educational Values

Abstrak: Maguti merupakan tradisi yang masih ada di masyarakat Ngawi, Jawa Timur. Penelitian ini bertujuan untuk mendeskripsikan makna simbol-simbol perlengkapan dan proses pelaksanaan serta nilai-nilai pendidikan budi pekerti yang terkandung dalam tradisi Maguti. Metode yang digunakan dalam penelitian ini adalah metode kualitatif. Penelitian ini dilakukan di dua puluh tempat di Kabupaten Ngawi, yaitu Desa Jagir, Tulakan, Bayem Taman, Bayem Sidoarjo, Jagir Krajan, Kalitengah, Tempon, Kedungjambe, Plembeku, Gedangan, Mojoagung, Miripencil, Mirirejo, Tretes, Duwet, Duwet Plasong, Duwet Dawungan, Mojorejo, Jomblang, Sampung, Karangdempel. Perlengkapan dan proses dalam pelaksanaan tradisi Maguti sebagai kajian utama dalam penelitian ini. Penelitian ini dilakukan di Ngawi, Jawa Timur, Indonesia. Hasil penelitian adalah terdapat simbol-simbol berupa perlengapan dan proses pelaksanaan tradisi Maguti. Perlengkapan dalam tradisi maguti adalah bucu, jenang abang putih, jenang sepuh, banyu suci, kembang setaman, sego udhuk, sego golong, gedhang setangkep, asahan, kopat lepet. Nilai-nilai pendidikan budi pekerti yang terkandung dalam tradisi Maguti adalah nilai keagamaan, nilai kemandirian, nilai kepedulian, nilai bertanggung jawab, nilai saling menghargai, nilai kejujuran, dan nilai kreatif.

Kata kunci: Maguti, Nilai Pendidikan Budi Pekerti 


\section{PENDAHULUAN}

Pendidikan budi pekerti sangat diperlukan manusia. Ellen G. White (dalam Kurniawan, 2013) menjelaskan bahwa pendidikan budi pekerti menjadi usaha paling penting yang pernah diberikan kepada manusia. Pendidikan budi pekerti menjadi tujuan luar biasa dari suatu sistem pendidikan yang benar. Oleh karena itu, pendidikan budi seharusnya mampu membawa peserta didik ke pengenalan nilai secara kognitif, penghayatan nilai secara afektif, dan hingga akhirnya masuk ke dalam pengalaman nilai secara nyata.

Banyak hasil penelitian yang menunjukkan bahwa budi pekerti seseorang dapat mempengaruhi kesuksesannya. Satu di antaranya berdasarkan penelitian yang dilakukan di Harvard University, Amerika Serikat menunjukkan bahwa ternyata kesuksesan seseorang tidak semata-mata ditentukan oleh pengetahuan dan kemampuan teknis saja, tetapi lebih pada kemampuan mengelola diri dan orang lain. Penelitian tersebut mengungkapkan bahwa kesuksesan hanya ditentukan sekitar 20 persen oleh hard skill dan sisanya 80 persen oleh soft skill (Zubaedi, 2011).

Hasil penelitian yang lainnya yaitu Marvin Berkowitz dari University of Missouri-St. Louis, menunjukkan peningkatan motivasi peserta didik di sekolah dalam meraih prestasi akademik pada sekolah-sekolah yang menerapkan pendidikan budi pekerti. Kelas-kelas yang secara komprehensif terlibat dalam pendidikan budi pekerti menunjukkan penurunan drastis pada perilaku negatif peserta didik yang dapat menghambat keberhasilan akademik (Kurniawan, 2013).

Pendidikan budi pekerti berkaitan erat dengan komponen-komponen pengetahuan moral tradisi, penalaran moral, belas kasih, altruisme, dan kecenderungan moral. Kirshenbaum (1995) menjelaskan bahwa kecenderungan moral meliputi berhati nurani, mencintai kebaikan, dapat menguasai diri, rendah hati, kebiasaan moral dan kehendak baik. Hal itu Sejalan pendapat Zuchdi (2010) yang mengungkapkan bahwa pendidikan budi pekerti bersifat menyeluruh atau komprehensif, menyangkut banyak aspek yang terkait menjadi satu kesatuan. Istilah komprehensif dalam pendidikan budi pekerti tersebut mencakup berbagai aspek, antara lain: isi, metode, proses, subjek, evaluasi.

Asmani (2011) menjelaskan bahwa pendidikan budi pekerti dapat diklasifikasikan menjadi empat jenis. Pertama, nilai budi pekerti kaitannya dengan Tuhan, bersifat religius. Kedua, nilai budi pekerti yang hubungannya dengan diri sendiri yang meliputi jujur, bertanggung jawab, 
bergaya hidup sehat, disiplin, kerja keras, percaya diri, berjiwa wirausaha, berpikir logis, kritis, kreatif, inovatif, mandiri, ingin tahu, dan cinta ilmu. Ketiga, nilai budi pekerti yang hubungannya dengan sesama meliputi sadar hak dan kewajiban diri dan orang lain, patuh pada aturan sosial, menghargai karya dan prestasi orang lain, santun, serta demokratis. Keempat, nilai budi pekerti yang hubungannya dengan alam sekitar, berupa sikap dan tindakan yang selalu berupaya mencegah kerusakan pada lingkungan alam di sekitarnya.

Menemukan nilai luhur pendidikan budi pekerti dalam budaya Indonesia tidaklah sulit. Intinya, nilai-nilai budi pekerti dapat ditemukan dalam adat dan budaya setiap suku bangsa negeri ini. Satu di antaranya adalah budaya masyarakat Jawa. Nilai-nilaii luhur ini menjadi aspek utama yang diinternalisasikan kepada generasi muda melalui pendidikan budi pekerti.

Pelestarian budaya Jawa melalui pewarisan dari satu generasi kepada generasi berikutnya sangat perlu dilakukan sebagai ikhtiar dalam memberikan pemahaman yang tepat kepada masyarakat sehingga berbagai wujud budaya Jawa baik ide-ide, nilai-nilai, tata kelakuan, adat, kebiasaan atau perilaku berpola, maupun wujud kebudayaan yang berupa hasil karya tidak dipertentangkan dengan ajaran agama tertentu.

Tradisi dalam masyarakat Jawa yang sangat beragam menjadi sebuah kebanggaan sekaligus tantangan untuk melestarikan dan mewariskannya kepada generasi selanjutnya baik secara lisan maupun tulisan. Perkembangan zaman dapat menyebabkan berbagai dampak perubahan pada tradisi yang ada di masyarakat Jawa. Namun demikian, tidak semuanya tradisi mengalami perubahan dan bisa mempertahankan eksistensinya.

Maguti merupakan salah satu tradisi yang masih dilaksanakan dalam masyarakat Jawa, tepatnya di Kabupaten Ngawi, Jawa Timur. Inti tujuan dalam pelaksanaan tradisi tersebut adalah untuk menginginkan keselamatan. Sejalan dengan hal ini, Setiyadi (2015) mengungkapkan bahwa hakikat keselamatan adalah sebagai wujud syukur dalam mendapatkan berkah, selamat dan terhindar dari cobaan yang berat, rasa syukur, kehidupan yang aman dan tentram, terhindari dari malapetaka dan tolak balak. Selain itu, tradisi yang dilakukan oleh masyarakat adalah untuk mendekatkan diri kepada Tuhan dan menjalin silaturahmi dengan sesama.

Penelitian ini mengkaji tradisi Maguti dengan pokok kajian yaitu bagaimana makna simbolsimbol yang terkandung dalam tradisi Maguti; bagaimana nilai-nilai pendidikan budi pekerti yang terkandung dalam tradisi Maguti. Penelitian ini bertujuan memberikan mendeskripsikan makna 
simbol-simbol dalam pelaksanaan tradisi Maguti dan mendeskripsikan nilai-nilai pendidikan budi pekerti yang terkandung dalam tradisi Maguti.

\section{METODE PENELITIAN}

Penelitian ini menggunakan metode kualitatif. Perlengkapan dan proses dalam pelaksanaan tradisi Maguti sebagai kajian utamanya. Penelitian ini dilakukan di Ngawi, Jawa Timur, Indonesia. Teknik pengambilan data dalam penelitian ini dilakukan dengan wawancara terhadap informan kunci yaitu narasumber sesepuh desa. Selanjutnya, dilakukan observasi yang dilengkapi dengan catatan lapangan, refleksi, data divalidasi dengan triangulasi data. Dalam penelitian kualitatif realitas sosial dipandang sebagai sesuatu yang utuh, kompleks, dinamis, dan penuh makna (Sugiyono, 2013). Penelitian ini dilakukan di dua puluh tempat di Kabupaten Ngawi, yaitu Desa Jagir, Tulakan, Bayem Taman, Bayem Sidoarjo, Jagir Krajan, Kalitengah, Tempon, Kedungjambe, Plembeku, Gedangan, Mojoagung, Miripencil, Mirirejo, Tretes, Duwet, Duwet Plasong, Duwet Dawungan, Mojorejo, Jomblang, Sampung, Karangdempel. Dari desa-desa tersebut, sampai saat ini masih rutin melaksanakan tradisi Maguti sehingga bisa dikatakan berkontribusi sangat besar dalam upaya melestarikan tradisi tersebut.

\section{HASIL DAN PEMBAHASAN}

\section{Makna Simbol-Simbol Yang Terkandung dalam Tradisi Maguti}

\section{Data 1}

"siram kepisan cahyaning bocah koyo tanggal sepisan utawa tanggal siji, siram kepindho cahyaning bocah koyo tanggal loro teko tanggal limolas".

Makna dari simbol kegiatan di atas adalah pada pelaksanaan tradisi Maguti, pada prosesi siraman pertama, cahaya wajahnya bocah yang telah dipaguti seperti tanggal satu (seoalah-olah bersinar terang), siraman kedua cahaya wajahnya bocah yang dipaguti seperti tanggal dua, begitupun seterusnya sampai siraman ke limabelas yaitu sama terangnya bulan purnama pada tanggal tersebut. Hal itu merupakan simbol dari sebuah harapan hari demi hari kebaikan tetap menaungi salah satunya bisa berupa dikelilingi oleh hal-hal yang positif/baik-baik/keberuntungan. 


\section{Data 2}

"mengeti soko bapa biyung utawi kakang kawah adi ari-ari, ninimong kaki among sing momong jiwo ragane sing di paguti ingkang manggon kiblat sekawan enem pancer".

Maknanya, memperingati bahwa manusia asalnya dari bapak (putih), ibu (merah) atau air dan ari-ari sukma yang menjaga jiwa dan raganya anak yang dipaguti, bertempat di kiblat empat enam pancer, maksudnya timur-barat, utara-selatan, atas-bawah. Hal tersebut merupakan simbol bahwa masyarakat Jawa sangat menjunjung tinggi penghormatan kepada orang tua, khususnya bapak dan ibu. Selain itu, masyarakat Jawa juga mempercayai bahwa dalam diri seseorang itu ada yang selalu membersamai dan berada di empat penjuru mata angin.

\section{Data 3}

"mengeti sedulur tua, kakang kawah adi ari-ari"

Maknanya memperingati saudara tua, orang yang melahirkan pertama itu mengeluarkan air dan daging yang menempel pada pusar. Hal ini menjadi simbol bahwa manusia Jawa sangat menghargai asal-usulnya, satu di antaranya keberadaan tali pusar atau bagian yang menempel pada bagian tubuhnya. Masyarakat Jawa biasanya menanam tali pusar di dalam rumah ketika ada keluarga yang melahirkan. Hal itu merupakan salah satu wujud untuk sarana pengingat asalmuasal yang disebutnya "sedulur tua" atau saudara tua.

\section{Data 4}

"kangge mengeti kanjeng Nabi Rosul sak garwa putra sak kabat sekawan Usman, Umar, Syaidina, Ngali"

Maknanya, memperingati nabi dan rasul, istri dan anaknya, serta sahabatnya Usman, Umar, Syaidina, Ngali. Hal ini menunjukkan simbol bahwa masyarakat Jawa telah mengenal agama, dalam konteks ini adalah agama Islam. Hal itu ditunjukkan dengan adanya sebuah usaha untuk selalu mengeti (mengingat) nabi Muhammad S.A.W. beserta anak istrinya, juga sahabatsahabatnya. Artiya, dari sisi kepercayaan, dalam tradisi ini sudah ada unsur yang berkaitan dengan agama Islam.

\section{Data 5}

"kangge caos dhahar memule ninidayang kakidayang ingkang manggen wonten kiblat sekawan lima pancer bapa angkasa ibu bumi ingkang dilenggahi ingkang kagungan hajat kasuwun berkah pangestunipun ingkang wilujeng ngajeng sak pawingkingipun" 
Maknanya, memperingati leluhur perempuan, laki-laki yang bertempat di kiblat empat lima pancer. Lima pancer maksudnya timur-barat,utara-selatan, yang ditempati yang dipaguti. Hal tersebut sebagai manifestasi simbol bahwa masyarakat Jawa menyadari dalam kehidupannya selalu ada yang mengikuti dalam setiap aktivitasnya, yakni leluhurnya baik leluhur perempuan maupun laki-laki yang keberadaannya di empat penjuru mata angin.

\section{Data 6}

"kangge ngintun sedaya leluhuripun jaler estri sepuh anem tebih celak kasuwuni idi pangestunipun ingkang wilujeng"

Maknanya, memperingati para leluhur laki-laki perempuan, tua-muda, jauh-dekat dimintai doa restu yang baik. Seperti pada penjelasan sebelumnya, bahwa masyarakat Jawa sangat menghargai keberadaan leluhurnya yang dianggap terdapat di empat penjuru mata angin. Oleh sebab itu, masyarakat Jawa senantiasa berdoa setiap saat untuk meminta keselamatan dirinya, leluhurnya kepada sang pencipta.

\section{Data 7}

"kangge mengeti kanjeng nabi Sulaiman ingkang ngratoni godhong, kayu, banyu, pithik ingkang kangge uba rampe menika"

Maknanya, memperingati nabi Sulaiman yang menguasai dedaunan, kayu, air, ayam atau semua hewan yang disembelih untuk perlengkapan tradisi-tradisi dalam masyarakat Jawa. Daun yang di maksud adalah untuk membungkus atau alas nasi, kayu dan air maksudnya untuk memasak. Dalam hal ini, masyarakat Jawa juga menyadari bahwa nabi Sulaiman diberikan kekuatan yang istimewa dari Tuhan. Kekuatan istimewa itu di antaranya adalah bisa berbicara dengan hewan, tumbuhan, bahkan jin pun tunduk padanya. Oleh karena itu, masyarakat Jawa memanfaatkan hal-hal yang berkaitan dengan tumbuhan, hewan, dan segala yang diperlukan dalam pelaksanaan tradisi, sangat perlu mengingat keistimewaan yang diberikan Tuhan hanya kepada nabi Sulaiman.

\section{Data 8}

"dene sedaya uba rampe kangge mengeti dinten pitu pekenan gangsal sasi rolas windu wolu wuku tigangdoso bale lan griyo tanem tuwoh raja koyo jangkepipun dinten menika wilujeng ngajeng sak wingkingipun" 
Maknanya, memperingati tujuh hari (senin, selasa, rabu, kamis, jumat, sabtu, dan minggu), pasaran lima (pon, wage, kliwon, legi, pahing), satu tahun maksudnya dua belas bulan, satu windu maksudnya delapan tahun, jumlah wuku ada tiga puluh, pekarangan dan rumah yang ditempati, tanaman yang ditanam, hewan yang dipelihara, semua itu hari tersebut selamat dari sekarang sampai besok. Intinya, simbol dalam sebuah harapan akan keselamatan dalam melaksanakan semua kegiatan.

\section{Nilai-nilai Pendidikan Budi Pekerti Masyarakat Jawa dalam Tradisi Maguti}

Masyarakat Jawa mempunyai nilai-nilai pendidikan budi pekerti yang terdapat dalam tradisi Maguti. Nilai-nilai tersebut termanifestasi dalam perlengkapan tradisi Maguti. Berdasarkan hasil wawancara dari sesepuh desa dan observasi langsung dalam pelaksanaan tradisi Maguti, berikut ini perlengkapan yang mengandung nilai-nilai pendidikan budi pekerti.

\section{Nilai Keagamaan}

Bucu merupakan nasi yang berbentuk kerucut, dalam tradisi Maguti, bucu menjadi simbol dari gunung yang menerangkan adanya interpretasi terhadap doa manusia yang menuju ke atas (Tuhan), Tumuju marang pengeran (tertuju kepada Tuhan); Dedonga anteng, meneng, metentheng (berdoa dengan tenang, diam dan teguh). Berpijak dari hal itu, bucu dalam tradisi Maguti ini mengandung nilai pendidikan budi pekerti yaitu nilai keagamaan. Hal tersebut ditunjukkan dengan adanya sikap dan perilaku yang patuh dalam mengikuti ajaran agama yang dianut, salah satunya wujudnya ialah ajaran untuk sentiasa berdoa kepada Tuhan.

Jenang abang putih yang terbuat dari beras yang direbus, ditambah parutan kelapa (putih) ditambahkan gula Jawa dan garam. Putih sebagai simbol dari ayah sedangkan merah simbol dari ibu. Hal tersebut mengandung adanya nilai pendidikan budi pekerti berupa nilai keagamaan, karena berkaitan jika dimaknai lebih mendalam Jenang abang putih memiliki arti asal mula Tuhan menciptakan manusia yakni bertemunya sel sperma dengan sel telur.

\section{Nilai Kemandirian}

Perlengkapan bucu antara laint: Bothok yang terbuat dari parutan kelapa, daun mlinjo, tempe, cabai, garam, bawang merah, bawang putih, dan dibungkus dengan daun pisang kemudian dikukus. Kulub yaitu daun singkong, kacang panjang, kecambah, bayam kemudian direbus, serta dicampur sambal yang dibuat dari parutan kelapa, cabai, bawang putih, penyedap rasa yang dikukus. Pelas, terbuat dari isi kacang panjang yang tua, ditumbuk lembut kemudian dicampur 
dengan parutan kelapa, bawang putih, penyedap rasa, dibungkus dikukus. Endhok (telur), harus telur ayam yang direbus, dikupas boleh satu ataupun dua. Jika satu harus dibelah jadi dua atau empat. Semua itu harus hasil dari tanaman dan hewan ternak milik sendiri. Hal ini menunjukkan adanya nilai pendidikan budi pekerti, yaitu nilai kemandirian.

\section{Nilai Kepedulian}

Jenang Sepuh, terbuat dari bekatul direbus ditambah garam. Maknanya untuk memperingati air dan ari-ari. Banyu suci berasal dari air bersih yang ditaburi bunga setaman. Bunga Setaman ini melambangkan ada aneka ragam yang mengelilingi kehidupan manusia. Kembang akan mengembang dan menumbuhkan kesenangan. Hal tersebut mengandung adanya nilai pendidikan budi pekerti berupa nilai kepedulian lingkungan yang terdapat dalam "banyu suci" dan "kembang setaman" untuk memperoleh tentunya harus adanya kepedulian lingkungan dengan cara menjaga keberadaanya.

\section{Nilai Bertanggung jawab}

Sego udhuk, berasal dari beras yang direbus, dicampur dengan santan kelapa, daun salam, garam. Perlengkapannya meliputi : Jangan lombok, terbuat dari kentang, tempe, kapri, cabai, bawang merah dan putih, digoreng, air santan kelapa, daun salam, penyedap rasa, gula Jawa direbus. Srundeng, terbuat dari parutan kelapa muda yang digoreng, bumbunya ketumbar, garam, penyedap, gula Jawa. Krupuk abang, terbuat dari pathi garut. Jenang abang putih, terbuat dari beras yang dicampur parutan kelapa dan direbus, untuk warna merahnya berasal dari gula Jawa. Hal tersebut mempunyai makna simbol untuk leluhur. Hal itu juga mengandung nilai pendidikan budi pekerti yaitu nilai bertanggung jawab untuk senantiasa tidak melupakan leluhur (orang tua).

\section{Nilai Saling Menghargai}

Sego golong jumlahnya ada tujuh, merupakan nasi yang dibentuk bulat berjumlah tujuh. Mempunyai makna pitutur/pituah. Perlengkapannya meliputi : Ayam panggang, yaitu ayam yang dipanggang dengan diberi bumbu garam, bawang putih, dan penyedap rasa. Jangan lombok, terbuat dari kentang, tempe, kapri, cabai, bawang merah dan putih, digoreng, air santan kelapa, daun salam, penyedap rasa, gula Jawa direbus. Srundeng, terbuat dari parutan kelapa muda yang digoreng, bumbunya ketumbar, garam, penyedap, gula Jawa. Krupuk abang, terbuat dari pathi garut dan berwarna merah. Nilai pendidikan budi pekerti ialah nilai menghargai prestasi, 
maksudnya dalam hal ini sikap dan tindakan yang berupa "tujuh pitutur" diakui berguna bagi masyarakat.

\section{Nilai Kejujuran}

Dele ireng yakni kedelai yang digoreng. Maknanya adalah dahulu menurut cerita para leluhur nabi tidak menyukai tempe, sukanya kedelai yang digoreng. Lalapan, terbuat dari bawang merah, cabai, garam. Maknanya ialah untuk saling melengkapi. Ayam ingkung, ayam yang direbus dengan bumbu ketumbar, bawang putih, daun salam, santan direbus. Pisang Ayu yaitu pisang dua sisir, sirih, nginang, tembakau, gambir, njet, uang. Semua itu mengandung makna saling melengkapi, jika ada yang kurang bersedia jujur untuk menyampaikan demi kebaikan bersama. Hal ini menunjukkan adanya pendidikan budi pekerti nilai kejujuran ykni adanya sikap keterbukaan.

\section{Nilai Kreatif}

Asahan jumlahnya ada dua, terbuat dari nasi yang dibentuk seperti piring yang di atasnya diberi daun pisang yang dibentuk bundar yang disebut samir. Isinya jangan lombok, srundeng, jeroan ayam, krupuk abang. Kopat lepet, terbuat dari janur yang dianyam diisi beras yang dicampur parutan kelapa diberikan garam direbus. Sedangkan lepet terbuat dari beras ketan yang ditambah dengan parutan kelapa ditambah garam dibungkus dengan daun bambu, diikat dengan merang atau dami. Semua dibentuk dengan rapi dan indah. Nilai pendidikan budi pekerti yang terkandung di dalamnya berupa nilai kreatif.

\section{KESIMPULAN}

Tradisi Maguti bagi masyarakat Jawa memiliki tujuan untuk membuang segala hal yang negatif, demi tercapainya suatu keselamatan. Perlengkapan yang menjadi simbol dalam tradisi maguti adalah bucu, jenang abang putih, jenang sepuh, banyu suci, kembang setaman, sego udhuk, sego golong, gedhang setangkep, asahan, kopat lepet. Adapun nilai-nilai pendidikan budi pekerti yang terkandung dalam tradisi Maguti antara lain nilai keagamaan, nilai kemandirian, nilai kepedulian, nilai bertanggung jawab, nilai saling menghargai, nilai kejujuran, dan nilai kreatif.

Tradisi Maguti bagi masyarakat Jawa, khususnya di Ngawi Jawa Timur adalah sebuah aset yang sangat berharga dan harus dilestarikan, oleh sebab itu, pemerintah bersama semua pihak harus berperan aktif dalam mewujudkan pelestarian tradisi tersebut demi terjaga eksistensinya.

Nilai-nilai pendidikan budi pekerti yang terkandung dalam tradisi Maguti harus ditindak lanjuti 
dengan mengembangkannya menjadi salah satu bahan ajar yang dapat diimplemetasikan dalam materi pelajaran di sekolahan, baik dari jenjang Sekolah Dasar sampai ke Perguruan Tinggi.

\section{DAFTAR PUSTAKA}

Asmani, Jamal Ma'aur. (2011). Buku Panduan Internalisasi Pendidikan Karakter di Sekolah. Yogyakarta : Diva Press.

Eni Sugiarti. (2007). “Marginalisasi Wanita Madura: Implikasi Program Keluarga Berencana di Desa Banyuwulu (sebuah paradigma etnosains). Jurnal humaniora Vol. 2 No.2, 89-104.

H. Iin Wariin Basyari. (2014). Nilai-nilai kearifan lokal (LOCAL WISDOM) tradisi memitu pada masyarakat Cirebon (Studi Masyarakat Desa Setupatok Kecamatan Mundu). Jurnal Edunomic Vol. 2 No. 1, 47-56.

Herawati, E. N. (2014). Nilai-nilai Karakter Yang Terkandung Dalam Dolanan Anak Pada Festival Dolanan Anak Se-DIY. Jurnal Penelitian Vol. 13 No. 1.

Jismulatif and Dahnilsyah,(2019). Language and Ecology in Ecolinguistics Perspective : A Case Study on Tunjuk Ajar Language in Riau, Indonesia. J. Phys.: Conf. Ser. 1351012068 https://doi.org/10.1088/1742-6596/1351/1/012068

Kirschenbaum, Howard. (1995). 100 Ways to Enhance Values and Morality in Schools and Youth Settings. Boston : Allyn and Bacon.

Kuntoro, Sodiq A. (2012). Konsep Pendidikan Berbasis Kearifan Lokal sebagai Dasar Pembentukan Karakter Bangsa. Prosiding Seminar Nasional Ilmu Pendidikan. Program Studi Ilmu Pendidikan Pascasarjana Universitas Negeri Makassar.

Kurniawan, Syamsul. (2013). Pendidikan Karakter Konsep dan Implementasinya Secara Terpadu Di Lingkungan Keluarga, Sekolah, Perguruan Tinggi, dan Masyarakat. Yogyakarta : Ar-Ruzz Media.

Nining Nur'Aini, Wakidi, Muhammad Basri. (2013). Tradisi upacara nadran pada masyarakat nelayan Cirebon di Kelurahan Kangkung Bandar Lampung. Jurnal Kebudayaan Unila.

Noor, Rohimah M. (2011). Pendidikan Karakter Berbasis Sastra Solusi Pendidikan Moral yang Efektif. Yogyakarta : Arr-russ Media.

Pajar Hatma Indra Jaya. (2012). Dinamika pola pikir orang Jawa ditengah arus modernisasi. Jurnal Humaniora Vol. 24 No. 2, 133-140.

Rosniati Hakim (2014). Pembentukan Karakter Peserta Didik Melalui Pendidikan Berbasis Al-Quran. Jurnal Pendidikan Karakter, Vol. 4 No. 2, 123-135.

Rukiyati dan L. Andriani Purwastuti (2016). Model Pendidikan Karakter Berbasis Kearifan Lokal Pada Sekolah Dasar Di Bantul Yogyakarta. Jurnal Pendidikan Karakter, Vol. 6 No. 1, 130-142.

S. Reksosusilo. (2006). Ruwatan dalam budaya Jawa. Jurnal Studia Philosophica et Theologica, Vol. 6 No. 1, 32-53. 
Setiawan, K.E.P. (2019). Makna dan Nilai Ajaran Budi Pekerti dalam Tradisi Maguti. Jurnal Metalingua, Vol. 4 No. 2, 1-6.

Setiawan, K.E.P. (2019). Maguti: Kajian Simbolisme Budaya Jawa. Cirebon: Eduvision.

Setiyadi, T. (2015). Makna Simbol Selamatan Kematian Pada Masyarakat Jawa. Lamongan: Lentera IImu.

Sri Wening. (2012). Pembentukan Karakter Bangsa Melalui Pendidikan Nilai. Jurnal Pendidikan Karakter, Vol. 2 No. 1, 55-66.

Sutardjo, Imam. (2012). Kajian Budaya Jawa. Surakarta: Jurusan Sastra Daerah Fakultas Sastra dan Seni Rupa Universitas Sebelas Maret Surakarta.

Wagiran (2012). Pengembangan Karakter Berbasis Kearifan Lokal Hamemayu Hayuning Bawana : Identifikasi Nilai-nilai Karakter Berbasis Budaya. Jurnal Pendidikan Karakter, Vol. 2 No.3, 329338.

Wahab, Abdul Aziz (2012). Pengelolaan Pendidikan Berbasis Kearifan Lokal. Prosiding Seminar Nasional IImu Pendidikan. Program Studi Ilmu Pendidikan Pascasarjana Universitas Negeri Makassar.

Wahyudin, Uyu. (Ed). (2012). Membidik Untuk Membentuk Karakter: Bagaimana Sekolah Dapat Memberikan Pendidikan tentang Sikap Hormat dan Bertanggung jawab. Jakarta : Bumi Aksara.

Waryunah Irmawati. (2013). Makna simbolik upacara siraman pengantin adat Jawa. Jurnal Walisongo Vol. 21 No. 2, 309-330.

Wibowo, Agus. (2016). Manajemen Pendidikan Karakter Di Sekolah. Yogyakarta : Pustaka Pelajar.

Yuli Widiyono (2013). Nilai Pendidikan Karakter Tembang Campursari Karya Manthous. Jurnal Pendidikan Karakter, Vol. 3 No.2, 231-239.

Zuchdi, Darmayanti. (2010). Humanisasi Pendidikan Menemukan Kembali Pendidikan yang Manusiawi. Jakarta : Bumi Aksara. 